\title{
Development of a sustainable bioprocess based on green technologies for xylitol production from corn cob
}

\author{
Sara L. Baptista ${ }^{\mathrm{a}}$, Luís C. Carvalho ${ }^{\mathrm{b}}$, Aloia Romaní ${ }^{\mathrm{a}, *}$, Lucília Domingues ${ }^{\mathrm{a}}$ \\ ${ }^{a}$ CEB - Centre of Biological Engineering, University of Minho, 4710-057, Braga, Portugal \\ ${ }^{\mathrm{b}}$ Universidade Católica Portuguesa, CBQF - Centro de Biotecnologia e Química Fina - Laboratório Associado, Escola Superior de Biotecnologia, Rua Diogo Botelho 1327, \\ 4169-005, Porto, Portugal
}

\section{A R T I C L E I N F O}

\section{Keywords:}

autohydrolysis

added-value chemical

corn cob whole-slurry

industrial Saccharomyces cerevisiae

simultaneous saccharification and fermentation xylitol

\begin{abstract}
A B S T R A C T
In this work, a sustainable and environmental friendly strategy for the biotechnological production of xylitol was proposed and optimized. For this purpose, corn cob was hydrothermally pretreated at high solid loadings (25\%) for an efficient solubilization of xylan in hemicellulose derived compounds, xylooligosaccharides and xylose. Xylose enriched streams were obtained from the enzymatic saccharification of the whole slurry (solid and liquid fraction) resulting from the autohydrolysis pretreatment. The xylitol production in a simultaneous saccharification and fermentation (SSF) process, by the recombinant Saccharomyces cerevisiae PE-2-GRE3 strain, was optimized using different enzyme and substrate (pretreated corn cob solid) loadings by an experimental design. This study demonstrated a significant effect of substrate loading on the production process achieving a maximal concentration of $47 \mathrm{~g} / \mathrm{L}$ with $6.7 \%$ of pretreated corn cob and $24 \mathrm{FPU} / \mathrm{g}$ of enzyme loading, with partial detoxification of the hydrolysate. Furthermore, the 1.42-fold increase in xylitol titer and 1.56-fold increase in productivity achieved in a SSF using an acetic acid free-hydrolysate evidenced the negative effect of acetic acid on the yeast-based xylitol production process. The combination of these green technologies and the optimization of the proposed strategy enhanced the overall xylitol production through the valorization of corn cob.
\end{abstract}

\section{Introduction}

The excessive dependence of non-renewable fossil resources and the need for climate change mitigation are the main driving forces for the development of novel technologies to produce high value chemicals from renewable resources. Lignocellulosic biomass, which includes plant-derived materials from wood and grass to agro-industrial residues, is the most abundant renewable feedstock and appears to be the most promising starting material for high value chemicals production (Bedő et al., 2019; Sheldon, 2018).

Xylitol is included within the twelve building blocks that can be produced from lignocellulosic sugars and subsequently converted to a number of valuable derivatives for food, pharmaceutical and chemistry industries (Bozell and Petersen, 2010; Cortivo et al., 2018; Dall Cortivo et al., 2020). It is a naturally occurring sugar alcohol that presents a sweetness profile similar to sucrose but with $40 \%$ less calories. In addition to its low-caloric content, exhibits other benefits especially antidiabetic and anti-cariogenic properties (Salli et al., 2019). Currently, xylitol is commercially produced by hydrogenation of xylose extracted from lignocellulosic biomass. In this production process, xylose- enriched hydrolysates are obtained through acid hydrolysis of hemicellulose and subsequent concentration. In spite of using an inexpensive and renewable raw material, is not environmental-friendly and requires large energy requirements. In this sense, the production of xylitol through microbial fermentation of sugars from renewable feedstocks has gained increasing interest (Dasgupta et al., 2017).

There is a wide range of xylose-fermenting yeasts able to produce xylitol as a by-product of xylose utilization pathway (Abdul Manaf et al., 2018). However, xylitol yields are limited by the use of xylose as carbon source for yeast growth and maintenance energy. To overcome this limitation, the expression of enzymes with xylose reductase activity in Saccharomyces cerevisiae, naturally incapable of xylose utilization, has shown to increase the conversion of xylose into xylitol close to the maximum theoretical yield ( $\sim 100 \%)$, since the produced xylitol is not further metabolized (Baptista et al., 2018; Hallborn et al., 1991; Jo et al., 2015; Kogje and Ghosalkar, 2016). Moreover, the possibility of using robust $S$. cerevisiae strains, isolated from harsh environmental industrial conditions, with higher tolerance to the lignocellulosic-derived inhibitors represents another advantage for xylitol production in lignocellulose-based processes (Cunha et al., 2019; Pereira et al., 2014a,

\footnotetext{
* Corresponding author.

E-mail address: aloia@ceb.uminho.pt (A. Romaní).
} 


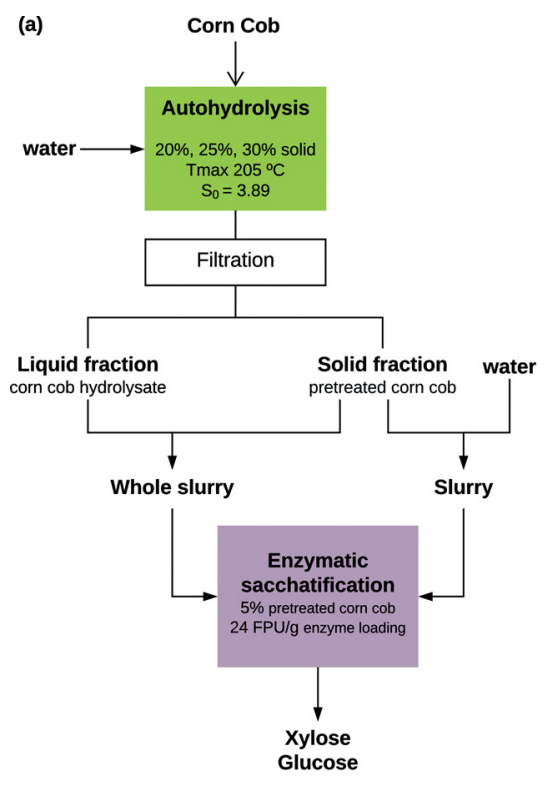

(b)

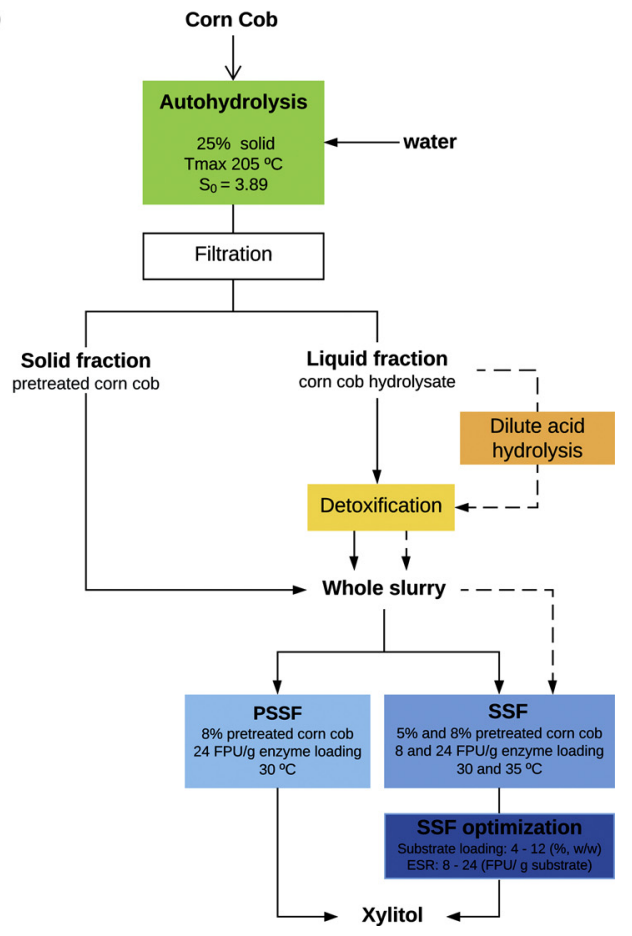

Fig. 1. Flowchart of experimental procedure for (a) evaluation of the effect of autohydrolysis pretreatment at different different solid loadings on enzymatic saccharification and (b) optimization of operational conditions and process configuration for xylitol production using whole slurry corn cob. Dotted lines refer to an optional strategy for xylitol production by the complete removal of acetic acid from hemicellulosic hydrolysate. 2014b). Considering this, the $S$. cerevisiae PE-2 industrial strain presenting innate capacity for xylitol accumulation (Romani et al., 2015), was recently engineered to overexpress an endogenous aldose reductase with xylose reductase activity (encoded by GRE3 gene) and efficiently used as whole-cell biocatalyst for xylitol production (Baptista et al., 2018).

Among lignocellulosic biomass, corn cob is potentially the most favorable feedstock for xylitol production due its high xylan content (Xu et al., 2017). Nevertheless, the main challenge of corn cob processing, like other lignocellulosic materials, is the requirement of pretreatment technologies to break down its recalcitrant structure and to obtain xylose enriched hemicellulosic hydrolysates (Morales et al., 2018). Hydrothermal pretreatment (also known as autohydrolysis) represents an environmental friendly alternative to dilute acid hydrolysis, the most common pretreatment to solubilize the hemicellulosic fraction in lignocellulose-based xylitol production processes (Abdul Manaf et al., 2018; Hernandéz-Peréz et al., 2019). The autohydrolysis method, using water as reaction media, yields a liquid fraction mainly composed by xylooligosaccharides (XOS) and increases cellulose accessibility to enzymatic hydrolysis (González-García et al., 2018; Romaní et al., 2010; Ruiz et al., 2020). The hemicellulosic derived compounds (oligosaccharides) can be hydrolysed by acid or enzymes. Enzymatic hydrolysis of XOS offers several advantages compared to acid hydrolysis since it occurs at milder operational conditions with less inhibitory compounds formation and does not require neutralization procedures before fermentation (Hu et al., 2016). Given the limited research on enzymatic hydrolysis of XOS and also in the valorization of whole-slurry (containing both cellulose and xylooligosaccharides polysaccharides in solid and liquid fractions, respectively) in presence of lignocellulosederived inhibitors, (Hu et al., 2016; Romaní et al., 2014b) the main goal of this work is the development a high effective strategy using green technologies (autohydrolysis, enzymatic saccharification and fermentation) for xylitol production from corn cob.

\section{Materials and Methods}

\subsection{Raw material and autohydrolysis pretreatment}

Corn cob was milled to a particle size less than $8 \mathrm{~mm}$, homogenized and submitted to autohydrolysis. The raw material was mixed with water at different solid loadings: 20,25 and $30 \mathrm{~g}$ of corn cob solid dry weight per $100 \mathrm{~g}$ of water, and heated to $205^{\circ} \mathrm{C}$ in a $2 \mathrm{~L}$ stainless steel reactor (Parr Instruments Company) equipped with Parr PDI temperature controller. Temperature and time of autohydrolysis was correlated using the following equation, which allows the determination of severity factor $\left(R_{0}\right)$ expressed as severity $\left(S_{0}=\log R_{0}\right)$ as follows:

$S_{0}=\log \left[\int_{0}^{t_{\max }} \frac{T(t)-T_{r e f}}{\omega} \cdot d t+\int_{t_{\max }}^{t_{f}} \frac{T^{\prime}(t)-T_{r e f}}{\omega} \cdot d t\right]$

where, $t_{\max }$ and $t_{f}$ refers to the time (min) required to achieve the maximum temperature and the $t_{0}$ is referred to time of the heatingcooling profiles (limited by $\mathrm{T}_{\text {ref }}$ ), respectively, while $\mathrm{T}(\mathrm{t})$ and $\mathrm{T}^{\prime}(\mathrm{t})$ correspond to the temperature profiles for the stages of heating and cooling. $\mathrm{T}_{\text {ref }}$ is the reference temperature $(373.15 \mathrm{~K})$ and $\omega$ is an empirical parameter related to the activation energy, set to $14.75 \mathrm{~K}$ for corn cob.

After treatment, liquid and solid fractions were separated by filtration and solid fraction (pretreated corn cob) was recovered and washed for Solid Yield (SY) determination. Chemical composition of corn cob and pretreated corn cob was analyzed following NREL protocols (NREL/TP-510-42618-42622-4218). The concentrations of sugars, acetic acid and furan compounds were measured by HPLC. For determination of oligosaccharides and acetyl groups, one aliquot of hydrolysate was submitted to an analytical hydrolysis (4\% w/ $/ \mathrm{w} \mathrm{H}_{2} \mathrm{SO}_{4}$ at $121^{\circ} \mathrm{C}$ for $20 \mathrm{~min}$ ).

\subsection{Enzymatic saccharification of pretreated corn $c o b$}

Enzymatic saccharification of pretreated corn cob was carried out at $45^{\circ} \mathrm{C}, 150 \mathrm{rpm}$ in an orbital shaker using $5 \%$ of pretreated corn cob and $24 \mathrm{FPU} / \mathrm{g}$ of enzyme loading for $96 \mathrm{~h}$. Commercial enzyme preparation used in these assays was Cellic CTec2 (kindly supplied by Novozymes, 
Bagsvaerd, Denmark). Cellulase and hemicellulase activities of Cellic CTec2 were $122 \mathrm{FPU} / \mathrm{mL}$ and $9764 \mathrm{U} / \mathrm{mL}$, determined following the procedures previously described (Bailey et al., 1992; Ghose, 1987). Enzymatic saccharifications were carried out using pretreated corn cob as substrate in water (named slurry) and pretreated corn cob in hydrolysate (named whole slurry) as shown in Fig. 1a. Glucose and xylose concentrations were analyzed by HPLC. Glucose (GY) and xylose yield (XY) were calculated following the equations:

$G Y(\%)=\frac{G_{t}-G_{t 0}}{\mathrm{G}_{P O T}} 100$

where, Gt is the glucose concentration $(\mathrm{g} / \mathrm{L})$ achieved at time $t$ and $\mathrm{Gt}_{0}$ is the glucose concentration at the beginning of the experiments; whereas $\mathrm{G}_{\mathrm{POT}}$ represents the potential glucose concentration that was calculated as:

$G_{P O T}=B f \frac{180}{162}$

where, B is dry corn cob biomass concentration $(\mathrm{g} / \mathrm{L})$, $\mathrm{f}$ is glucan fraction in dry biomass ( $g$ per $g$ ) and 180/162 is the stoichiometric factor that converts glucan to equivalent glucose.

$X Y(\%)=\frac{X_{t}-X_{t 0}}{X_{P O T}} 100$

where, $\mathrm{Xt}$ is the xylose concentration $(\mathrm{g} / \mathrm{L})$ achieved at time $t$ and $\mathrm{Xt}_{0}$ is the xylose concentration at the beginning of the experiments, whereas $\mathrm{X}_{\mathrm{POT}}$ represents the potential xylose concentration that was calculated as:

$X_{P O T}=B f \frac{150}{132}+X O S$

where, B is dry corn cob concentration $(\mathrm{g} / \mathrm{L}), \mathrm{f}$ is xylan fraction in dry biomass ( $\mathrm{g}$ per $\mathrm{g}$ ) 150/132 is the stoichiometric factor that converts xylan to equivalent xylose, and XOS is xylooligosaccharides concentration measured as xylose equivalent in $\mathrm{g} / \mathrm{L}$ present in the hydrolysate (XOS were only considered for potential xylose for the enzymatic saccharification of whole slurry).

\subsection{Yeast strain and inoculum}

The yeast strain used in this work was the yeast strain Saccharomyces cerevisiae PE-2, isolated from $1^{\text {st }}$ generation bioethanol plants in Brazil, (Basso et al., 2008; Pereira et al., 2014a, 2014b; Pereira et al., 2011, 2010) overexpressing the endogenous GRE3 gene, S. cerevisiae PE-2-GRE3 (Baptista et al., 2018). Yeast strain was maintained at $4{ }^{\circ} \mathrm{C}$ on YPD plates $(10 \mathrm{~g} / \mathrm{L}$ yeast extract, $20 \mathrm{~g} / \mathrm{L}$ peptone, $20 \mathrm{~g} / \mathrm{L}$ glucose and $20 \mathrm{~g} / \mathrm{L}$ agar) supplemented with $200 \mathrm{mg} / \mathrm{L}$ of geneticin (G418). Yeast cells for inoculation were grown overnight at $30{ }^{\circ} \mathrm{C}$ and $200 \mathrm{rpm}$ in YPD medium supplemented with $150 \mathrm{mg} / \mathrm{L}$ of G418. The cell suspension was collected by centrifugation for $5 \mathrm{~min}$ at $3000 \mathrm{rpm}, 4^{\circ} \mathrm{C}$ and suspended in $0.9 \%(\mathrm{w} / \mathrm{v})$ sodium chloride solution. The fermentation experiments were conducted with a cellular concentration of $11 \mathrm{~g}$ and $22 \mathrm{~g}$ fresh yeast/L corresponding to $5 \mathrm{~g}$ and $10 \mathrm{~g}$ of dry yeast/L, respectively.

\subsection{Preparation of corn cob hydrolysate: detoxification, neutralization and sterilization}

Corn cob hydrolysate and corn cob hydrolysate after dilute acid hydrolysis $\left(0.5 \% \mathrm{w} / \mathrm{w}\right.$ of $\mathrm{H}_{2} \mathrm{SO}_{4}$ for $165 \mathrm{~min}$ at $\left.125^{\circ} \mathrm{C}\right)$ (Rivas et al., 2006) were submitted to ion exchange detoxification to remove acetic acid, as previously described (Rodríguez-López et al., 2012). Briefly, corn cob hydrolysates were mixed with Amberlite IR-120 cationic resin (in $\mathrm{H}^{+}$form) at a mass ratio of $10 \mathrm{~g}$ cationic resin per gram of hydrolysate for $1 \mathrm{~h}$ with agitation. Cationic resin was recovered by filtration and the hydrolysate was treated for $2 \mathrm{~h}$ under agitation with Mto-
Dowex M43 anionic resin (in $\mathrm{OH}^{-}$form) at a mass ratio of $20 \mathrm{~g}$ anionic resin per gram of acetic acid present in the hydrolysate. The resulted acid-hydrolysed corn cob hydrolysate was neutralized with $\mathrm{CaCO}_{3}$ until $\mathrm{pH} 5$ and the pH of corn cob hydrolysate was adjusted with $\mathrm{NaOH}$ or $\mathrm{HCl}$ solutions. Both hydrolysates were sterilized by filtration $(0.2 \mu \mathrm{m})$ and added to solid fraction (sterilized at $121^{\circ} \mathrm{C}$ for $20 \mathrm{~min}$ ) to obtain the whole-slurry used for xylitol production.

\subsection{Pre-saccharification and Simultaneous Saccharification and Fermentation (PSSF and SSF) assays of corn cob whole slurry}

Simultaneous saccharification and fermentation (SSF) and Pre-saccharification and simultaneous saccharification and fermentation (PSSF) assays of whole-slurry were carried out in Erlenmeyer flasks at $30{ }^{\circ} \mathrm{C}$ and/or $35^{\circ} \mathrm{C}$ in an orbital shaker at $200 \mathrm{rpm}$. For PSSF, an enzymatic saccharification step of whole slurry was carried out for $24 \mathrm{~h}$ using $8 \%$ solids at 8 or $24 \mathrm{FPU} / \mathrm{g}$ at $45^{\circ} \mathrm{C}$ and $200 \mathrm{rpm}$. After this step, temperature was decreased up to $35^{\circ} \mathrm{C}$ for cell inoculation. For determination of operational conditions, SSF assays were carried out using 5 and/or $8 \%$ of solids (pretreated corn cob). To evaluate the effect of acetic acid SSF assays were carried out using $6.76 \%$ of solid, $24 \mathrm{FPU} / \mathrm{g}$ at $35^{\circ} \mathrm{C}$ and corn cob hydrolysate with or without diluted acid posthydrolysis. Corn cob hydrolysate medium was supplemented with $20 \mathrm{~g} / \mathrm{L}$ of peptone and $10 \mathrm{~g} / \mathrm{L}$ of yeast extract.

\subsection{Experimental design of Simultaneous Saccharification and Fermentation of whole slurry}

Simultaneous saccharification and fermentation (SSF) process conditions were evaluated and optimized following a full factorial design ( 2 factors with two replicates of the central point, 10 total experiments). The independent variables evaluated were: solid loading of pretreated corn cob or $\mathrm{x}_{1}$ (ranged between 4-12\% w/w) and enzyme to substrate ratio (ESR) or $\mathrm{x}_{2}$ (ranged between 8-24 FPU/g). Dependent variables were correlated with the independent variables by empirical models, following the equation:

$y_{j}=b_{0 j}+\sum_{i=1}^{2} b_{i j} x_{i}+\sum_{i=1}^{2} \ldots \sum_{k \geq i}^{2} b_{i k j} x_{i} x_{k}$

where $y_{j}\left(j=1\right.$ to 3 ) is the dependent variable; $x_{i}$ or $x_{k}$ (i or $k: 1$ to 2 , $k \geq i)$ are the normalized, independent variables and $b_{0 j} \ldots b_{i k j}$ are regression coefficients calculated from experimental data by multiple regression using the least-squares method. The experimental data were fitted to the proposed models using commercial software (Microsoft Excel, Microsoft Office 365 ProPlus).

\subsection{Determination of fermentation parameters}

Xylitol yield $\left(\mathrm{Y}_{\mathrm{XL}}\right)$ and productivity $\left(\mathrm{Q}_{\mathrm{pt}}\right)$ were calculated as follows:

$Y_{X L}=\frac{[X L]_{t}}{\left[X_{P O T}\right]} \cdot 100$

where, $\mathrm{XL}$ is the concentration of xylitol at time $t, \mathrm{X}_{\mathrm{POT}}$ is the potential xylitol considering the xylose, xylooligosaccharides and the xylan present in the SSF.

$Q p_{t}=\frac{[X L]_{t}}{t}$

where $[\mathrm{XL}]$ is xylitol concentration at time $t$ divided by time $t$.

\subsection{Analytical methods}

Samples from saccharification and fermentation assays, chemical characterization and autohydrolysis treatment (including solid and hydrolysate) of corn cob were analyzed for quantification of sugars 
(glucose, xylose, arabinose), acetic acid, xylitol, furfural, hydroxymethylfurfural (HMF) and ethanol by HPLC using a BioRad Aminex $\mathrm{HPX}-87 \mathrm{H}(300 \times 7.8 \mathrm{~mm})$ column, at $60^{\circ} \mathrm{C}$, and $0.005 \mathrm{M}$ sulfuric acid as eluent in a flow rate $0.6 \mathrm{~mL} / \mathrm{min}$. The peaks corresponding to sugars, acetic acid, xylitol and ethanol were detected using a Knauer-IR intelligent refractive index detector, whereas furfural and HMF were detected using a Knauer-UV detector set at $280 \mathrm{~nm}$.

\section{Results and discussion}

\subsection{Autohydrolysis pretreatment for corn cob processing: effect of solid loading}

The xylitol production from lignocellulosic biomass depends on the fractionation pretreatment used to obtain xylose for the bioconversion process (Dasgupta et al., 2017; Hernandéz-Peréz et al., 2019). In this study, the hydrothermal pretreatment of corn cob at high solid content (between $20 \%$ and $30 \%$ ) was evaluated in order to maximize xylan solubilization and recovery the hemicellulose derived compounds, especially xylose and xylooligosaccharides. The biomass processing strategy proposed for xylitol production is shown in Fig. 1b.

Corn cob was chemically analyzed and its composition (based on three replicates) was: $28.8 \% \pm 1.63$ of glucan, $29.6 \% \pm 1.88 \mathrm{~g}$ of xylan, $22.9 \% \pm 0.30 \mathrm{~g}$ of Klason lignin, $3.4 \% \mathrm{~g} \pm 0.83$ of arabinan and $2.0 \% \pm 0.04 \mathrm{~g}$ of acetyl groups per $100 \mathrm{~g}$ of dry weight.

The pretreatment severity was based on previous works that have shown that the use of $12 \mathrm{~g}$ of corn cob per $100 \mathrm{~g}$ of water lead to maximum concentration of xylooligosaccharides (Garrote et al., 2008; Rivas et al., 2006). In order to reduce the water consumption in the process and increase the xylose concentration in the liquid fraction (hydrolysate), the solid loading of corn cob was evaluated in the range of 20 to $30 \mathrm{~g}$ of corn cob per $100 \mathrm{~g}$ of water at $\mathrm{T}_{\max }$ of $205^{\circ} \mathrm{C}\left(\mathrm{S}_{0}=3.89\right)$ (Baptista et al., 2018). The use of high-solid loadings in the pretreatment minimizes the water consumption and reduces the energy required for heating, improving the economic and environmental sustainability of the process (Modenbach and Nokes, 2012; Jesus et al., 2017). Nevertheless, increased solid concentrations could negatively affect the process efficiency by insufficient mixing, limitations of heat and mass transfer and also by increasing the concentration of inhibitor compounds in the hydrolysate. Chemical composition of solid and liquid fractions after pretreatment is shown in Table 1 . The recovery of glucan and lignin in the solid phase varied in the range of 88.9-97.4 $\mathrm{g}$ of

Table 1

Chemical composition of solid and liquid fractions obtained from corn cob processing by autohydrolysis at Severity of 3.89 using high solid loading.

\begin{tabular}{|c|c|c|c|}
\hline $\begin{array}{l}\text { Solid loading ( } \mathrm{g} \text { of corn cob per } \\
100 \mathrm{~g} \text { of water) }\end{array}$ & 20 & 25 & 30 \\
\hline $\begin{array}{r}\text { Solid yield ( } \mathrm{g} \text { of autohydrolysed } \\
\text { corn cob/100 } \mathrm{g} \text { of corn cob) }\end{array}$ & 57.7 & 60.0 & 57.7 \\
\hline \multicolumn{4}{|c|}{ Autohydrolysed corn cob composition ( $\mathrm{g}$ of component $/ 100 \mathrm{~g}$ of pretreated corn cob) } \\
\hline Glucan & $48.6 \pm 0.6$ & $43.8 \pm 0.6$ & $44.4 \pm 0.1$ \\
\hline Xylan & $16.8 \pm 0.1$ & $17.0 \pm 0.2$ & $18.3 \pm 0.3$ \\
\hline Arabinan & $1.21 \pm 0.10$ & $1.29 \pm 0.11$ & $1.21 \pm 0.02$ \\
\hline Acetyl groups & $0.53 \pm 0.01$ & $\mathrm{ND}^{\mathrm{a}}$ & ND \\
\hline Klason Lignin & $19.4 \pm 0.6$ & $22.2 \pm 0.2$ & $21.2 \pm 0.1$ \\
\hline \multicolumn{4}{|l|}{ Liquid phase composition (g/L) } \\
\hline Glucose & $0.73 \pm 0.04$ & $0.75 \pm 0.06$ & $0.71 \pm 0.04$ \\
\hline Xylose & $2.87 \pm 0.14$ & $7.52 \pm 0.32$ & $8.80 \pm 0.44$ \\
\hline Arabinose & $1.31 \pm 0.07$ & $2.28 \pm 0.04$ & $2.09 \pm 0.1$ \\
\hline Acetic acid & $1.56 \pm 0.08$ & $2.26 \pm 0.15$ & $3.65 \pm 0.18$ \\
\hline Hydroxymethylfurfural (HMF) & $0.44 \pm 0.02$ & $0.26 \pm 0.01$ & $0.75 \pm 0.04$ \\
\hline Furfural (F) & $1.34 \pm 0.07$ & $1.29 \pm 0.06$ & $4.30 \pm 0.21$ \\
\hline Glucooligosaccharides (GOS) & $1.28 \pm 0.3$ & $3.15 \pm 0.05$ & $2.31 \pm 0.01$ \\
\hline Xylooligosaccharides (XOS) & $25.1 \pm 1.4$ & $35.75 \pm 1.10$ & $31.9 \pm 0.08$ \\
\hline Arabinooligosaccharides (ArOS) & $1.05 \pm 0.22$ & $\mathrm{ND}^{\mathrm{a}}$ & $0.50 \pm 0.03$ \\
\hline
\end{tabular}

${ }^{\text {a }}$ ND not detected. glucan/100 $\mathrm{g}$ of glucan and $60.2-71.7 \mathrm{~g}$ of lignin/100 $\mathrm{g}$ of lignin in raw material, respectively. Chemical composition of liquid fraction (Table 1) showed that the increase of solid loading up to $25 \%$ in the pretreatment resulted in the highest concentration of released xylooligosaccharides $(35.75 \mathrm{~g} / \mathrm{L})$. Therefore, under this condition, $51.4 \%$ of xylan (measured as sum of xylose and xylooligosaccharides) was recovered in the liquid fraction, corresponding to $43.3 \mathrm{~g} / \mathrm{L}$ of potential xylose that may be used as substrate for xylitol production. For a solid loading of $30 \%$, the concentration of XOS was lower $(31.9 \mathrm{~g} / \mathrm{L})$ due to dehydration of xylose to furfural $(4.3 \mathrm{~g} / \mathrm{L})$. Furthermore, this condition resulted in higher concentration $(3.65 \mathrm{~g} / \mathrm{L})$ of acetic acid, a degradation compound generated in situ during pretreatment that acts as catalyst for the hemicellulose hydrolysis (Garrote et al., 2017) and could be directly related to a higher degradation of xylose into furfural comparing to the conditions using 20 and $25 \%$ of solid loading. The effectiveness of pretreatments at high solid loadings ( $>15 \%$ ) has been demonstrated in several strategies, such as the process developed by Inbicon AS (Denmark) using hydrated wheat straw with recycled condensate or the wet explosion pretreatment of lobelly pine (Xiros et al., 2014). Similar solid loadings (20 and $25 \%$ ) were also tested for hydrothermal treatment of brewer's spent grain, generating higher oligosaccharides concentration using $25 \%$ of solid loading in the pretreatment (Pinheiro et al., 2019). In addition, presoaked wheat straw was maintained at temperatures between $195-205^{\circ} \mathrm{C}$ and residence time in the range of 6 12 min by injection of stream, resulting in a concentration of solids in the reactor between $23 \%$ and $28 \%(\mathrm{w} / \mathrm{w})$, with the correspondent whole slurries being used for ethanol production by SSF (Jørgensen et al., 2007).

Despite being an attractive strategy to obtain higher sugar concentration, the use of high solid loading in the pretreatment generates higher amounts of degradation compounds, such as furfural, hydroxymethylfurfural and acetic acid (Jørgensen et al., 2007). Among these compounds that have inhibitory effects on enzymatic and fermentation processes, acetic acid (measured as sum of acetic acid and acetyl groups) was the major product in the hydrolysates, varying in the range of 4.57 to $9.02 \mathrm{~g} / \mathrm{L}$, raising with the increase of solid loading (Pino et al., 2019).

\subsection{Enzymatic hydrolysis of corn cob slurry and whole slurry}

Considering that hemicellulose and lignin derived compounds present in the hydrolysate (i.e., xylooligosaccharides and phenolic compounds) could inhibit the enzyme activities, reducing the saccharification yield (Romaní et al., 2014a, 2014b), the enzymatic hydrolysis of both fractions resulting from biomass pretreatment were evaluated by enzymatic saccharification of slurry (pretreated corn cob and water) and the whole-slurry (pretreated corn cob and hydrolysate).

As expected, the glucose concentration and glucose yield were higher in the enzymatic saccharification assays of slurries (Fig. 2, Table 2) comparing with the results obtained from whole-slurries (Fig. 3, Table 2), showing a clear effect of hemicellulosic hydrolysates on cellulose saccharification. The negative effect oligosaccharides on cellulose saccharification was also demonstrated by the high glucose yield (99\%) achieved with the hydrolysate containing lower oligosaccharides content (pretreatment with $20 \%$ of solid loading) in comparison with the glucose yields $(<76 \%)$ achieved in the saccharifications of whole-slurries obtained from autohydrolysis using higher solid loadings (25 and 30\%). This effect was also described by Oliveira et al. (2018), which reported 25\% less glucose production for the enzymatic saccharification of eucalyptus whole-slurry.

In terms of xylose yield, the xylose concentration was inferior in the hydrolysate containing lower amount of xylooligosaccharides, resulting in a final xylose concentration of $36.8 \mathrm{~g} / \mathrm{L}$ ( $98 \%$ of xylose yield). The enzymatic saccharification of whole slurries obtained from the autohydrolysis with $25 \%$ and $30 \%$ of solid loading resulted in equivalent xylose concentrations ( 48.8 and $48.4 \mathrm{~g} / \mathrm{L}$, respectively) but the highest 
(a)

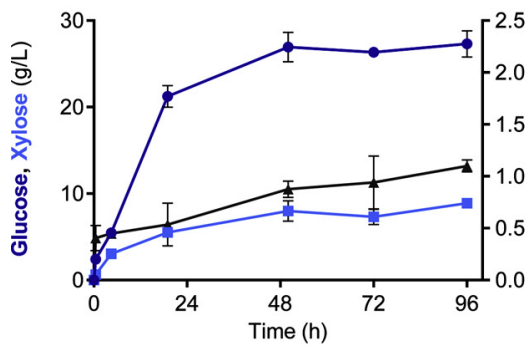

(b)

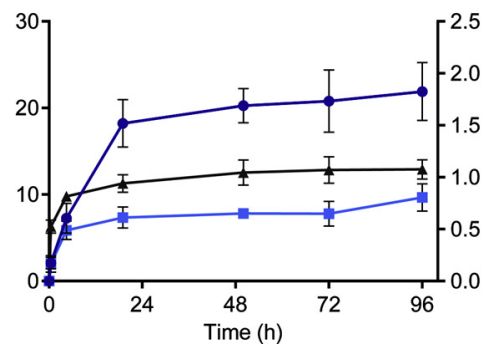

(c)

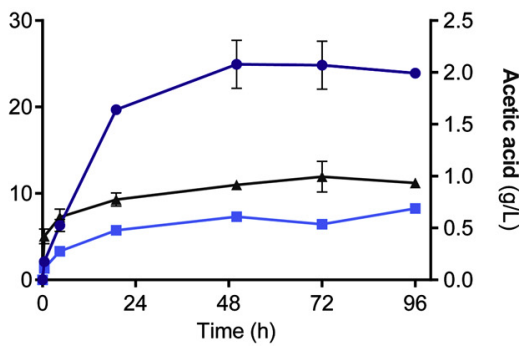

Fig. 2. Enzymatic saccharification of slurry using $5 \%$ of pretreated corn cob from autohydrolysis at (a) $20 \%$, (b) $25 \%$ (c) $30 \%$ of solid loading. Profiles of glucose, xylose and acetic acid concentrations.

Table 2

Operational conditions used in the enzymatic saccharification of 5\% pretreated corn cob using $24 \mathrm{FPU} / \mathrm{g}$ and main results (glucose concentration and yield and xylose concentration and yield) obtained at $96 \mathrm{~h}$.

\begin{tabular}{|c|c|c|c|c|c|}
\hline \multicolumn{2}{|c|}{ Operational Conditions } & \multicolumn{4}{|l|}{ Main Results } \\
\hline Substrate & Solid loading in autohydrolysis (\%, w/w) & Glucose concentration (g/L) & Glucose Yield (\%) & Xylose concentration (g/L) & Xylose Yield (\%) \\
\hline Slurry & 20 & 27.3 & 101.1 & 8.9 & 92.9 \\
\hline Whole-Slurry & & 28.8 & 99.4 & 36.8 & 97.8 \\
\hline Slurry & 25 & 21.9 & 90.0 & 9.7 & 100.0 \\
\hline Whole Slurry & & 23.1 & 72.3 & 48.8 & 90.5 \\
\hline Slurry & 30 & 23.9 & 97.0 & 8.3 & 79.4 \\
\hline Whole Slurry & & 21.5 & 75.0 & 48.4 & 93.5 \\
\hline
\end{tabular}

(a)

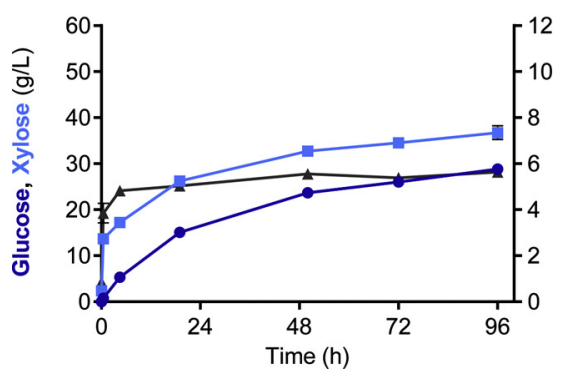

(b)

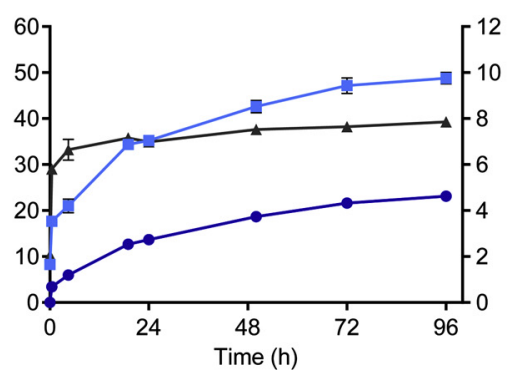

(c)

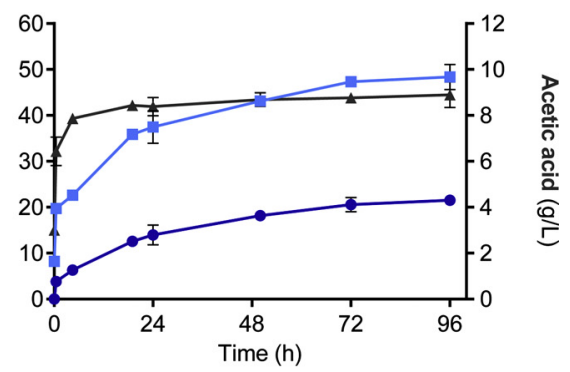

Fig. 3. Enzymatic saccharification of whole-slurry using $5 \%$ of pretreated corn cob from autohydrolysis at (a) $20 \%$, (b) $25 \%$ (c) $30 \%$ of solid loading. Profiles of glucose, xylose and acetic acid concentrations.

Table 3

Operational conditions (temperature, substrate and enzyme loading) of simultaneous saccharification and fermentation (SSF) and pre-saccharification and simultaneous saccharification and fermentation (PSSF) and main results obtained (xylitol concentration, yield and productivity).

\begin{tabular}{|c|c|c|c|c|c|c|c|c|}
\hline Run & \multicolumn{3}{|c|}{ Operational conditions } & \multicolumn{5}{|l|}{ Results } \\
\hline $\mathrm{SSF}_{30}$ & 30 & 5 & 24 & 52.93 & 11.92 & 48.69 & 91.99 & 0.336 \\
\hline $\mathrm{PSSF}_{1}$ & $45^{\circ} \mathrm{C} ; 35^{\circ} \mathrm{C}$ & 8 & 8 & 58.72 & 14.84 & 32.36 & 55.10 & 0.193 \\
\hline $\mathrm{PSSF}_{2}$ & $45^{\circ} \mathrm{C} ; 35^{\circ} \mathrm{C}$ & 8 & 24 & 58.72 & 11.94 & 37.96 & 64.64 & 0.226 \\
\hline $\mathrm{SSF}_{1}$ & 35 & 8 & 8 & 58.72 & 4.46 & 39.00 & 66.42 & 0.271 \\
\hline
\end{tabular}

${ }^{a} \mathrm{X}_{\text {pot }}$ potencial xylose, calculated considering the sum of xylose concentration in the $\mathrm{t}_{0}$ of SSF or PSSF with the xylose produced from xylan and XOS saccharification.

${ }^{b} X_{f}$ xylose concentration in the $t_{f}$.

c $\mathrm{Q}_{\max }$ maximal productivity, calculated when xylitol was maximum.

xylose yields ( $>95 \%$ ) were achieved using whole slurry obtained from the autohydrolysis with $20 \%$ of solid loading. A similar result $(21 \mathrm{~g} / \mathrm{L}$ of xylose corresponding to $93 \%$ of xylose yield) was observed with a hydrolysate obtained from industrial wheat straw processing (Ibicon and Beta-Renewable).(Hu et al., 2016)

The enzymatic cocktail used in the whole slurries assays (Fig. 3) also hydrolysed acetyl groups present in the hemicellulosic hydrolysate and pretreated solid corn cob, achieving a maximal concentration of acetic acid of $8.9 \mathrm{~g} / \mathrm{L}$ (Fig. 3c). In fact, weak acids such as acetic acid may inhibit the cell growth or increase the fermentation lag phase, affecting the fermentation performance in the subsequent step of xylose to xylitol bioconversion (Cunha et al., 2019, 2018; Palmqvist and Hahn- 
(a)

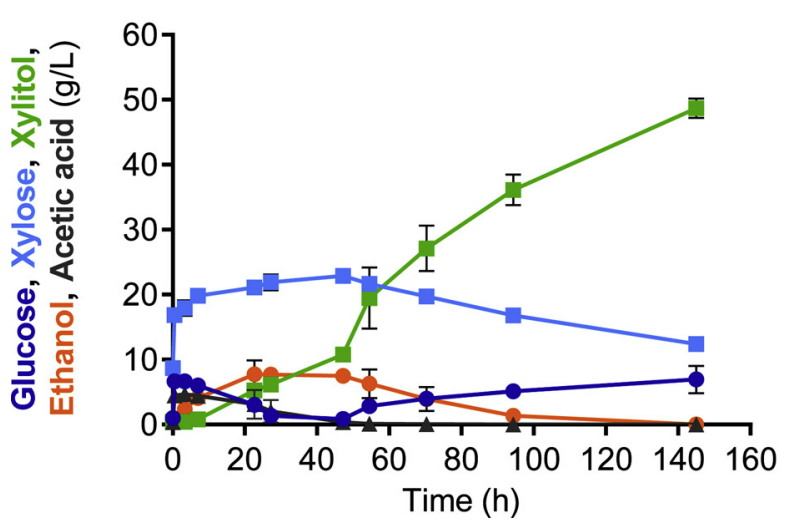

(b)

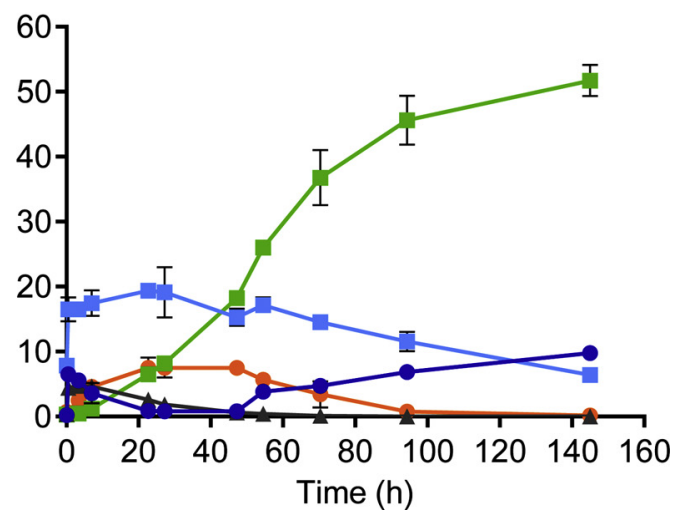

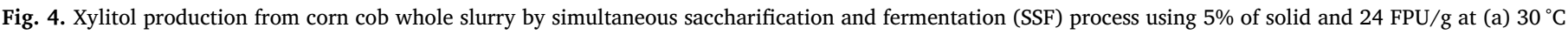
and (b) $35^{\circ} \mathrm{C}$.

(a)

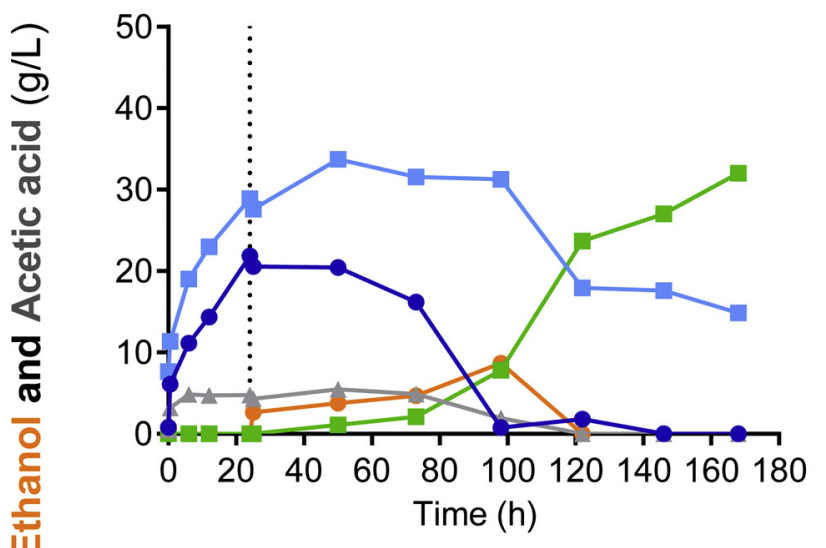

(c)

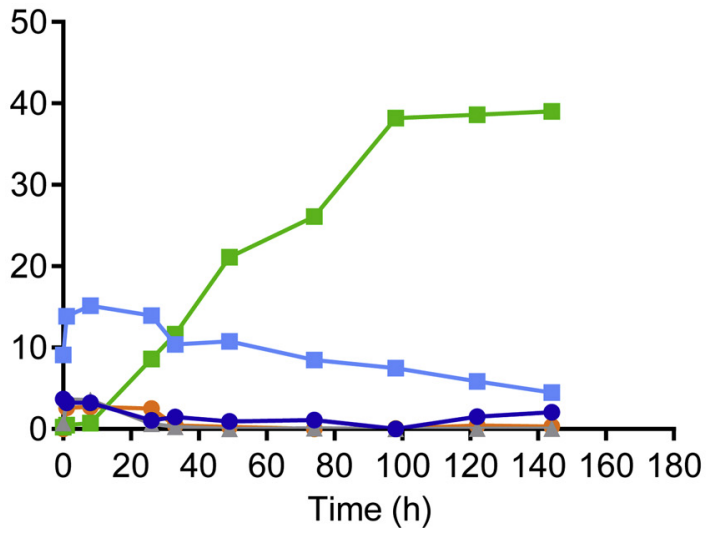

(b)

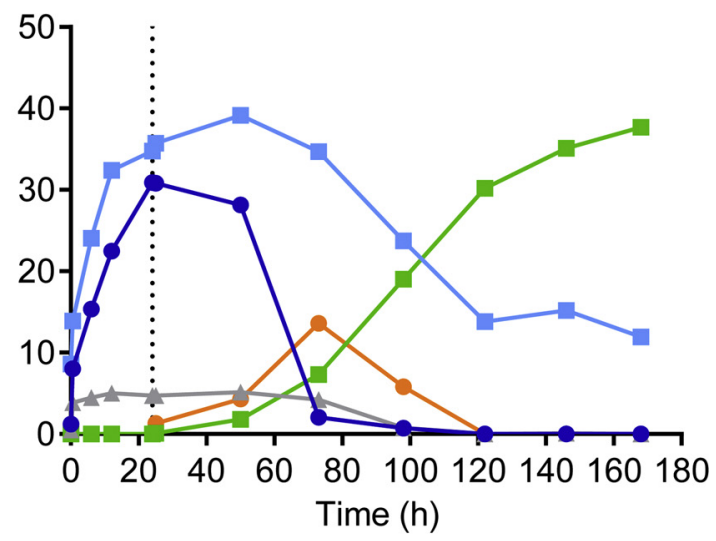

(d)

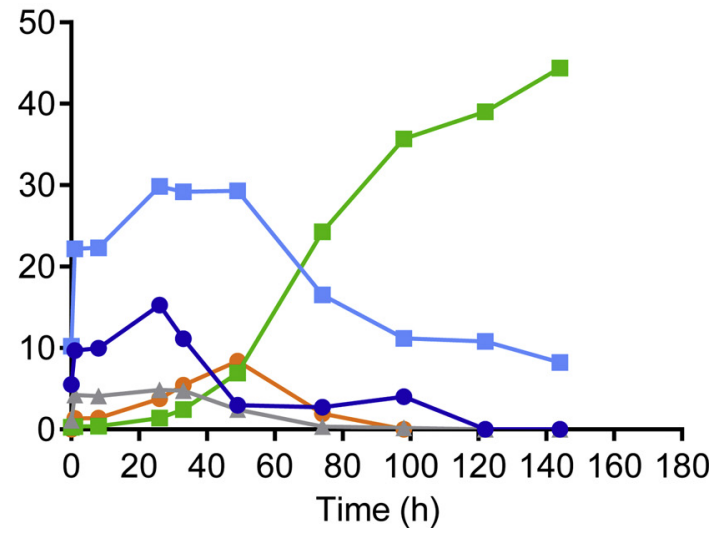

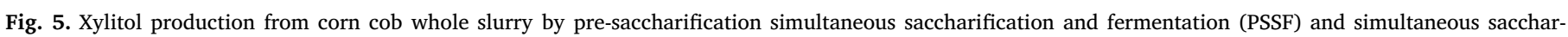

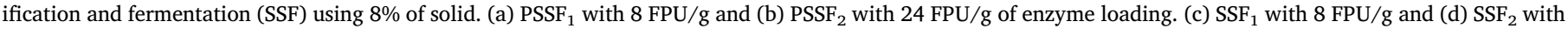
$24 \mathrm{FPU} / \mathrm{g}$ of enzyme loading. The dotted lines indicate the yeast inoculation time.

Hägerdal, 2000). Considering the results obtained from the enzymatic saccharification of whole-slurries, the autohydrolysis with $25 \%$ of corn cob showed to be more advantageous in terms of xylooligosaccharide conversion and xylose concentration. Therefore, this operational condition was selected for the xylose to xylitol bioconversion process. In addition, the hydrolysate was detoxified by anion exchange for a complete removal of free acid acetic, reducing the final concentration after enzymatic saccharification from $7.9 \mathrm{~g} / \mathrm{L}$ (Fig. $3 \mathrm{~b}$ ) to $5.6 \mathrm{~g} / \mathrm{L}$.
3.3. Determination of operational conditions for xylitol production using whole slurry corn $\mathrm{cob}$

The whole-cell bioconversion process for the production of xylitol involves the xylose transportation into the yeast cell and the conversion into xylitol by the aldose reductase encoded by the GRE3 gene. The yeast $S$. cerevisiae is a non-xylose-utilizing organism and therefore the recombinant PE-2-GRE3 strain need to be supplied with a carbon source to regenerate co-factors and ensure maintenance energy generation 
Table 4

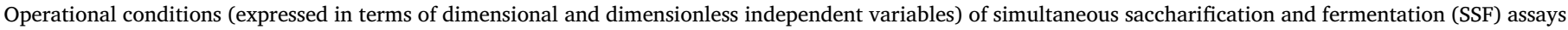
and experimental results obtained (xylose concentration, yield and productivity) for dependent variables $\mathrm{y}_{1}$ to $\mathrm{y}_{3}$.

\begin{tabular}{|c|c|c|c|c|c|c|c|}
\hline Run & $\mathrm{x}_{1}$ & $\mathrm{x}_{2}$ & Substrate loading $(\%, \mathrm{w} / \mathrm{w})$ & ESR (FPU/g substrate) & Final xylitol concentration $(\mathrm{g} / \mathrm{L})$ or $\mathrm{y}_{1}$ & Xylitol yield (\%) or $\mathrm{y}_{2}$ & Productivity $(\mathrm{g} / \mathrm{L} \cdot \mathrm{h})$ or $\mathrm{y}_{3}$ \\
\hline 1 & -1 & -1 & 4 & 8 & 22.8 & 45.6 & 0.19 \\
\hline 2 & 0 & -1 & 8 & 8 & 39.0 & 66.9 & 0.27 \\
\hline 3 & 1 & -1 & 12 & 8 & 24.6 & 37.0 & 0.17 \\
\hline 4 & -1 & 0 & 4 & 16 & 16.0 & 32.0 & 0.11 \\
\hline 5 & 0 & 0 & 8 & 16 & 40.3 & 69.0 & 0.28 \\
\hline 6 & 0 & 0 & 8 & 16 & 43.7 & 75.02 & 0.31 \\
\hline 7 & 1 & 0 & 12 & 16 & 11.1 & 16.7 & 0.08 \\
\hline 8 & -1 & 1 & 4 & 24 & 40.4 & 80.6 & 0.28 \\
\hline 9 & 0 & 1 & 8 & 24 & 40.0 & 68.6 & 0.28 \\
\hline 10 & 1 & 1 & 12 & 24 & 12.3 & 18.6 & 0.09 \\
\hline
\end{tabular}

Table 5

Regression coefficients, values and significance (based on a t-test).

\begin{tabular}{|c|c|c|c|c|c|c|}
\hline \multirow[t]{2}{*}{ Response variable } & \multicolumn{2}{|c|}{ Xylitol concentration } & \multicolumn{2}{|c|}{ Xylitol yield } & \multicolumn{2}{|c|}{ Xylitol productivity } \\
\hline & coefficient & $P$ value & coefficient & $P$ value & coefficient & $P$ value \\
\hline $\mathrm{b}_{0}$ & 38.63 & 0.0003 & 64.76 & 0.001 & 0.26 & 0.0007 \\
\hline $\mathrm{b}_{1}$ & -5.20 & 0.073 & -14.33 & 0.039 & -0.04 & 0.091 \\
\hline $\mathrm{b}_{2}$ & 1.78 & 0.455 & 3.05 & 0.553 & 0.002 & 0.924 \\
\hline$b_{12}$ & -7.45 & 0.047 & -13.37 & 0.082 & -0.04 & 0.129 \\
\hline$b_{11}$ & -21.71 & 0.003 & -33.20 & 0.012 & -0.14 & 0.010 \\
\hline$b_{22}$ & 6.44 & 0.135 & 10.27 & 0.247 & 0.04 & 0.227 \\
\hline $\mathrm{R}^{2}$ & 0.93 & & 0.94 & & 0.88 & \\
\hline Adjusted- $\mathrm{R}^{2}$ & 0.85 & & 0.77 & & 0.79 & \\
\hline $\mathrm{F}$ & 11.0 & & 6.9 & & 6.0 & \\
\hline Significance level & $98 \%$ & & $96 \%$ & & $95 \%$ & \\
\hline
\end{tabular}

(Hallborn et al., 1991). The glucan-enriched solid phase (obtained from corn cob autohydrolysis) can be efficiently hydrolysed by enzymes, providing glucose for cell metabolism during the bioconversion of $x y-$ lose (from corn cob hydrolysate) into xylitol (Baptista et al., 2018).

Considering that SSF process efficiency is strongly affected by the temperature, preliminary SSF experiments were performed at 30 and $35^{\circ} \mathrm{C}$ in order to evaluate its influence on xylitol production process (Table 3). As seen in Fig. 4, the use of 5\% of pretreated corn cob and 24 FPU/g of enzyme loading allows the release of both xylose and glucose from XOS and cellulose hydrolysis and subsequent utilization of xylose for xylitol production and glucose for cell metabolism. The increasing concentration of xylitol and the simultaneous accumulation of xylose in medium suggest that enzymatic hydrolysis occurs faster than the bioconversion process. After glucose depletion, the yeast started to utilize the earlier produced ethanol by switching metabolism from glycolysis to aerobic utilization of ethanol, which prevents the competitive inhibition of xylose uptake by glucose and might be involved with the increased xylitol conversion rate, observed during the ethanol consumption phase. Despite the similar trends in fermentation profiles, the SSF performed at $35^{\circ} \mathrm{C}$ resulted in a higher xylitol concentration $(51.7 \mathrm{~g} / \mathrm{L})$ and the maximal productivity was about 1.3 -fold higher $(0.52 \mathrm{~g} / \mathrm{L} \cdot \mathrm{h}$ at $70 \mathrm{~h})$ compared to $30^{\circ} \mathrm{C}(0.39 \mathrm{~g} / \mathrm{L} \cdot \mathrm{h}$ at $70 \mathrm{~h})$. In this sense, the subsequent $\mathrm{SSF}$ experiments were performed at $35^{\circ} \mathrm{C}$.

In addition, as SSF processes require an equilibrium between the optimum temperature for enzymatic hydrolysis and for yeast fermentation (Olofsson et al., 2008; Tomás-Pejó et al., 2014), the effect on xylitol production of a saccharification before the SSF process (PSSF pre-saccharification and simultaneous saccharification and fermentation) was investigated (Fig. 5). The pre-saccharification step was performed at optimum temperature for enzymatic hydrolysis, using $8 \mathrm{FPU} /$ $\mathrm{g}\left(\mathrm{PSSF}_{1}\right)$ and $24 \mathrm{FPU} / \mathrm{g}\left(\mathrm{PSSF}_{2}\right)$ of enzyme loading and $8 \%$ of pretreated corn cob. SSF assays without pre-saccharification were performed for comparison (Table 3)

As seen in Fig. $5 \mathrm{a}$, in the first $24 \mathrm{~h}$ of saccharification $28.9 \mathrm{~g} / \mathrm{L}$ of xylose and $21.8 \mathrm{~g} / \mathrm{L}$ of glucose were released from the whole slurry by using $8 \mathrm{FPU} / \mathrm{g}\left(\mathrm{PSSF}_{1}\right)$. After yeast inoculation, the glucose released from hydrolysis was entirely consumed and the ethanol produced was subsequently re-assimilated. However, the xylitol concentration ( $32 \mathrm{~g} /$ L) and xylitol productivity $(0.19 \mathrm{~g} / \mathrm{L} \cdot \mathrm{h})$ achieved in $\mathrm{PSSF}_{1}$ were lower compared to $\mathrm{SSF}_{1}$ (Fig. 5c) that resulted in $39 \mathrm{~g} / \mathrm{L}$ of xylitol and $0.27 \mathrm{~g} /$ $\mathrm{L} \cdot \mathrm{h}$ of productivity. In $\mathrm{PSSF}_{2}$, the utilization of $24 \mathrm{FPU} / \mathrm{g}$ increased the initial concentration of xylose and glucose to 34.7 and $30.9 \mathrm{~g} / \mathrm{L}$, respectively (Fig. 5b). This higher initial availability of sugars did not lead to higher xylitol production in comparison to the $\mathrm{SSF}_{2}$ (Fig. 5d) that was conducted without pre-saccharification $(37.9 \mathrm{~g} / \mathrm{L}, 0.22 \mathrm{~g} / \mathrm{L} \cdot \mathrm{h}$ vs $44 \mathrm{~g} / \mathrm{L}, 0.30 \mathrm{~g} / \mathrm{L} \cdot \mathrm{h})$. In fact, the catabolite repression caused by high glucose concentrations has been recognized for long as the main factor for xylose transport inhibition in yeast, since glucose and xylose uptake occurs by facilitated diffusion through the same transport system that present low affinity for xylose (Hamacher et al., 2002; Subtil and Boles, 2012). As the pre-saccharification, under the evaluated conditions, was found to have a negative effect on the maximal xylitol concentration and productivity, the following experiments were performed under SSF conditions.

\subsection{Optimization of Xylitol production by SSF process: Experimental design}

Considering the results obtained in preliminary assays, the SSF strategy at $35{ }^{\circ} \mathrm{C}$ was selected for optimization of xylitol production using an experimental design. For that, pretreated corn cob loading $\left(\mathrm{x}_{1}\right)$ and enzyme to substrate ratio-ESR $\left(\mathrm{x}_{2}\right)$ were selected as independent variables and the dependent variables were xylitol production at the end of SSF process $\left(\mathrm{y}_{1}\right)$, xylitol yield $\left(\mathrm{y}_{2}\right)$ and productivity $\left(\mathrm{y}_{3}\right)$. Table 4 includes the experimental matrix (dimensional and normalized, dimensionless independent variables) and dependent variables. Time course of SSF experiments (run 1-10) can be seen in Figure S1 included in Supporting information.

In spite of the removal of acetic acid from the pretreated corn cob hydrolysate by ion exchange, the detoxification process only removes the acetic acid released from the autohydrolysis pretreatment and during the subsequent whole slurry enzymatic saccharification, more acetic acid is produced as a result of hydrolysis of acetyl groups linked 
a)

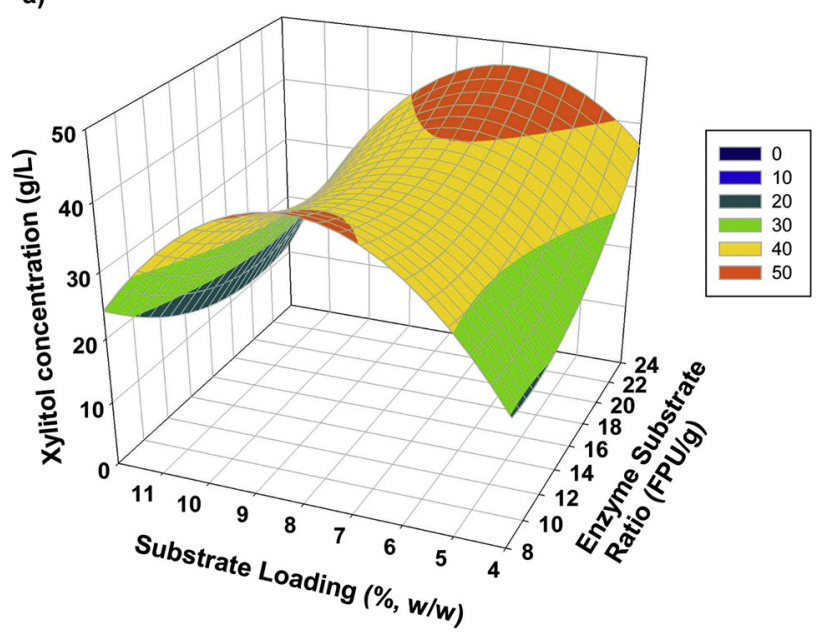

b)

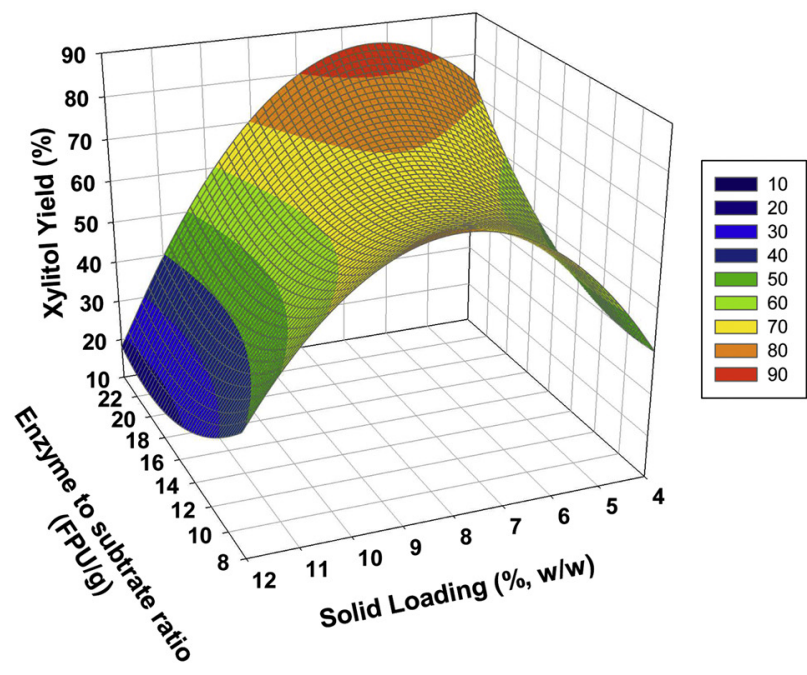

c)

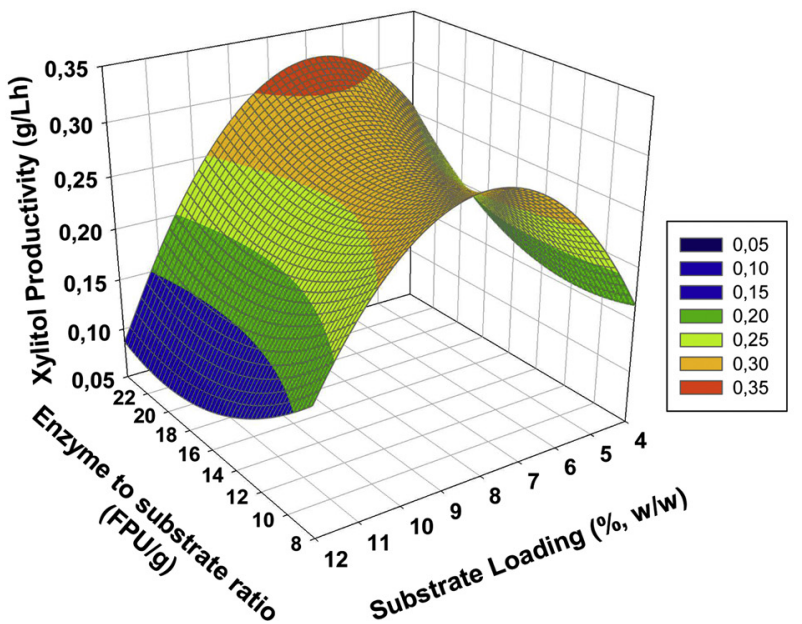

Fig. 6. Response surface for fitted for (a) xylitol concentration (g/L), (b) xylitol yield (\%) and (c) xylitol productivity ( $\mathrm{g} / \mathrm{L} \cdot \mathrm{h})$. to xylooligosaccharides. In the first hours of SSF experiments the concentrations of this compound achieved an average concentration of $4.3 \mathrm{~g} / \mathrm{L}$, which could explain the longer lag phases, affecting the overall productivity (Figure S1). The maximal xylitol concentrations ( $>40 \mathrm{~g} /$ L) were attained with the high enzyme loading (run 5, 6, 8 and 9) and substrate loadings (pretreated corn cob) lower than 8\% (Table 4). Whereas, the highest xylitol yield (81\%) was obtained with $4 \%$ of solid and $24 \mathrm{FPU} / \mathrm{g}$ of ESR (run 8). For a correct interpretation of the results, the experimental variables were correlated according to Equation (4). The fitting parameters were included in Table 5. The regression coefficients, the correspondent statistical significance (based in the Student's t test) and the significance of the model (based on Fisher's F parameter) measure the correlation and significance of the developed model for xylitol production by SSF. As seen in Table 5, linear and quadratic terms for variable $\mathrm{x}_{1}$ (substrate loading) and combination of substrate loading and ESR $\left(\mathrm{x}_{2}\right)$ were significant $(P<0.05 ; P<0.1)$. The coefficient $\mathrm{R}^{2}$ of model was $>0.9$ for xylitol concentration and yield, and only 0.88 for xylitol productivity.

The representation of the effect of independent variables on response variables were evaluated using a response surface model (Fig. 6). Although the use of high ESR improved xylitol production, this variable was not significant in the proposed model. Substrate loading was the variable with the more significant impact on xylitol production, yield and productivity, showing a clear optimum with a substrate loading of $6.8 \%$ at highest ESR (24 FPU/g). Under these conditions, xylitol yield was higher than $80 \%$. On the other hand, productivities were lower than $0.32 \mathrm{~g} / \mathrm{L} \cdot \mathrm{h}$, showing that the enzymatic saccharification of XOS and glucan could be limiting step of the process. The influence of solid loading on xylitol production could be related with the glucose catabolite repression, indicating that lower glucan concentration in the SSF is advantageous for xylitol production. According to the model, the optimum condition to maximize xylitol yield and productivity was $6.76 \%$ of substrate loading (w/w) and ESR of $24 \mathrm{FPU} / \mathrm{g}$. In order to validate this prediction, an additional SSF experiment was carried out under these conditions (Fig. 7a), resulting in a concentration of xylitol of $42.9 \mathrm{~g} / \mathrm{L}$ (at $144 \mathrm{~h}$ ) and xylitol productivity of $0.30 \mathrm{~g} / \mathrm{L} \cdot \mathrm{h}$, with a corresponding error of 7.66 and $6.66 \%$, respectively. These results verified the suitability of the model for predicting the experimental observations.

\subsection{Acid hydrolysis of hydrolysate for xylitol production by SSF}

As mentioned before, acetic acid can severely affect the fermentation performance of the yeast and decrease its xylitol production capacity. Considering this negative effect, the corn cob hydrolysate, composed by xylooligosaccharides linked to acetyl groups, was submitted to an acid posthydrolysis for depolymerization and deacetylation of xylooligosaccharides to yield free xylose and acetic acid. The acetic acid was completely removed from the resulting acid-hydrolysed hydrolysate by ion exchange detoxification and used in a SSF, under the previously optimized conditions. The recombinant strain tested in detoxified acid-hydrolysed liquor showed a superior fermentative capacity (Fig. 7b) converting xylose to xylitol considerably faster and producing 1.56 -fold more xylitol $(67.03 \mathrm{~g} / \mathrm{L})$ in comparing to SSF using enzymatic-hydrolysed autohydrolysis liquor (Fig. 7a). Additionally, as this process uses the yeast cells as whole-cell biocatalysts, the inoculum was increased up to $22 \mathrm{~g}$ wet cells/L to maximize the bioconversion of whole-slurry corn cob into xylitol (Fig. 7c). In fact, the increase of biocatalyst concentration resulted in higher xylitol concentration $(71.7 \mathrm{~g} / \mathrm{L})$, clearly improving the volumetric productivity at $48 \mathrm{~h}$ $(0.83 \mathrm{~g} / \mathrm{L} \cdot \mathrm{h}$ compared with $0.65 \mathrm{~g} / \mathrm{L} \cdot \mathrm{h}$ obtained with $11 \mathrm{~g} / \mathrm{L}$ of inoculum) and xylitol yield (94.6\% in comparison with $84.4 \%$ ).

This evaluation showed a strong negative effect of acetic acid on yeast performance and revealed a clear advantage in using an aceticacid deprived hydrolysate for an improved xylitol production. The inhibitory effect of this compound can be in part overcome by removing 
(a)

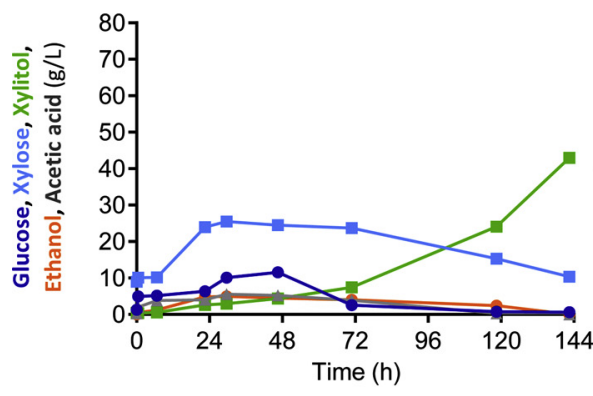

(b)

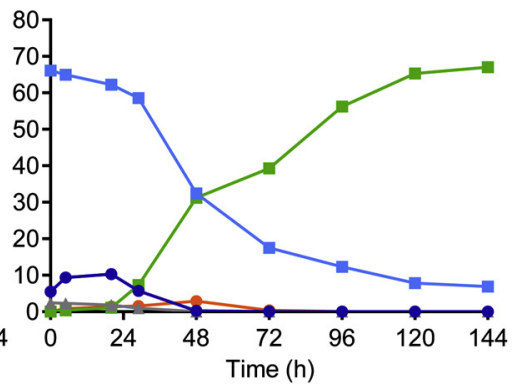

(c)

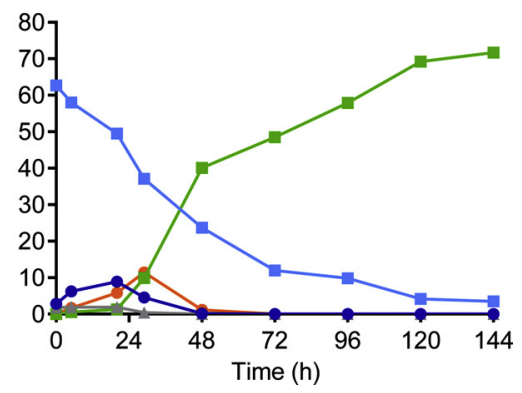

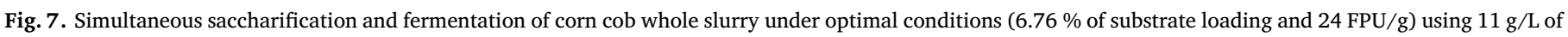
inoculum and (a) enzymatic hydrolysed hydrolysate; (b) acid-hydrolysed hydrolysate and (c) $22 \mathrm{~g} / \mathrm{L}$ of inoculum and acid-hydrolysed hydrolysate.

acid from the broth during the fermentation or through the development of metabolic engineering strategies, such as the overexpression of genes involved in acetic acid tolerance (Cunha et al., 2018; Weier et al., 1992). Moreover, the highest xylitol concentration obtained in this work (Fig. 7c) can be favorably compared to xylitol production reported in literature using concentrated hemicellulosic hydrolysates (Cheng et al., 2009; Kogje and Ghosalkar, 2017; Tada et al., 2012). Therefore, the use of high solid loadings in the pretreatment, approach followed in this work, is effective and avoids hydrolysate concentration steps, reducing time and cost of operation.

\section{Conclusions}

This work showed the feasibility of using high solid loadings in the hydrothermal pretreatment to obtain hydrolysates highly enriched in hemicellulose derived compounds (mainly xylooligosaccharides and xylose) suitable for the enzymatic hydrolysis and xylitol bioconversion, avoiding the need for costly evaporation steps. An experimental design was conducted to optimize the xylitol production by the recombinant $S$. cerevisiae strain. In addition, the absence of acetic acid resulted in the corn cob hydrolysate led to a further improved xylitol productivity and resulted in $72 \mathrm{~g} / \mathrm{L}$ of xylitol, which represent the highest titer reported in $S$. cerevisiae using lignocellulosic biomass. The results obtained in here demonstrate an efficient and sustainable xylitol production, applying green technologies (autohydrolysis and saccharification and fermentation) for an integrated valorization of lignocellulosic biomass.

\section{CRediT authorship contribution statement}

Sara L. Baptista: Conceptualization, Writing - original draft, Validation, Writing - review \& editing, Formal analysis. Luís C. Carvalho: Validation, Formal analysis. Aloia Romaní: Conceptualization, Writing - original draft, Validation, Writing - review \& editing, Funding acquisition. Lucília Domingues: Conceptualization, Validation, Writing - review \& editing, Funding acquisition.

\section{Declaration of Competing Interest}

The authors report no declarations of interest.

\section{Acknowledgment}

This study was carried out at the Biomass and Bioenergy Research Infrastructure (BBRI)- LISBOA-01-0145-FEDER-022059, supported by Operational Programme for Competitiveness and Internationalization (PORTUGAL2020), by Lisbon Portugal Regional Operational Programme (Lisboa 2020) and by North Portugal Regional Operational Programme (Norte 2020) under the Portugal 2020 Partnership Agreement, through the European Regional Development Fund (ERDF). This was also supported by the Portuguese Foundation for Science and
Technology (FCT) under the scope of the strategic funding of UIDB/ 04469/2020 unit, BioTecNorte operation (NORTE-01-0145 FEDER000004) funded by the European Regional Development Fund under the scope of Norte2020 and BIOVINO project (0688_BIOVINO_6_E) funded by INTERREG España - Portugal and European Regional Development Fund (ERDF). Sara L. Baptista (SFRH/BD/132717) thanks FCT for the doctoral fellowship.

\section{Appendix A. Supplementary data}

Supplementary material related to this article can be found, in the online version, at doi:https://doi.org/10.1016/j.indcrop.2020.112867.

\section{References}

Abdul Manaf, S.F., Md Jahim, J., Harun, S., Luthfi, A.A.I., 2018. Fractionation of oil palm fronds (OPF) hemicellulose using dilute nitric acid for fermentative production of xylitol. Ind. Crops Prod. 115, 6-15. https://doi.org/10.1016/j.indcrop.2018.01.067.

Bailey, M.J., Biely, P., Poutanen, K., 1992. Interlaboratory testing of methods for assay of xylanase activity. J. Biotechnol. 23, 257-270. https://doi.org/10.1016/01681656(92)90074-J.

Baptista, S.L., Cunha, J.T., Romaní, A., Domingues, L., 2018. Xylitol production from lignocellulosic whole slurry corn cob by engineered industrial Saccharomyces cerevisiae PE-2. Bioresour. Technol. 267, 481-491. https://doi.org/10.1016/j.biortech. 2018.07.068.

Basso, L.C., de Amorim, H.V., de Oliveira, A.J., Lopes, M.L., 2008. Yeast selection for fuel ethanol production in Brazil. FEMS Yeast Res. 8, 1155-1163. https://doi.org/10. 1111/j.1567-1364.2008.00428.x.

Bedő, S., Antal, B., Rozbach, M., Fehér, A., Fehér, C., 2019. Optimised fractionation of wheat bran for arabinose biopurification and xylitol fermentation by Ogataea zsoltii within a biorefinery process. Ind. Crops Prod. 139, 111504. https://doi.org/10.1016/ j.indcrop.2019.111504.

Bozell, J.J., Petersen, G.R., 2010. Technology development for the production of biobased products from biorefinery carbohydrates-the US Department of Energy's "Top 10" revisited. Green Chem. 12, 539-554. https://doi.org/10.1039/B922014C.

Cheng, K.K., Zhang, J.A., Ling, H.Z., Ping, W.X., Huang, W., Ge, J.P., Xu, J.M., 2009. Optimization of $\mathrm{pH}$ and acetic acid concentration for bioconversion of hemicellulose from corncobs to xylitol by Candida tropicalis. Biochem. Eng. J. 43, 203-207. https://doi.org/10.1016/j.bej.2008.09.012.

Cortivo, P.R.D., Hickert, L.R., Hector, R., Ayub, M.A.Z., 2018. Fermentation of oat and soybean hull hydrolysates into ethanol and xylitol by recombinant industrial strains of Saccharomyces cerevisiae under diverse oxygen environments. Ind. Crops Prod. 113, 10-18. https://doi.org/10.1016/j.indcrop.2018.01.010.

Cunha, J.T., Costa, C.E., Ferraz, L., Romaní, A., Johansson, B., Sá-Correia, I., Domingues, L., 2018. HAA1 and PRS3 overexpression boosts yeast tolerance towards acetic acid improving xylose or glucose consumption: unravelling the underlying mechanisms. Appl. Microbiol. Biotechnol. 102, 4589-4600. https://doi.org/10.1007/s00253-0188955-Z.

Cunha, J.T., Romaní, A., Costa, C.E., Sá-Correia, I., Domingues, L., 2019. Molecular and physiological basis of Saccharomyces cerevisiae tolerance to adverse lignocellulosebased process conditions. Appl. Microbiol. Biotechnol. 103, 159-175. https://doi. org/10.1007/s00253-018-9478-3.

Dall Cortivo, P.R., Hickert, L.R., Rosa, C.A., Záchia Ayub, M.A., 2020. Conversion of fermentable sugars from hydrolysates of soybean and oat hulls into ethanol and xylitol by Spathaspora hagerdaliae UFMG-CM-Y303. Ind. Crops Prod. 146, 112218. https://doi.org/10.1016/j.indcrop.2020.112218.

Dasgupta, D., Bandhu, S., Adhikari, D.K., Ghosh, D., 2017. Challenges and prospects of xylitol production with whole cell bio-catalysis: A review. Microbiol. Res. 197, 9-21. https://doi.org/10.1016/j.micres.2016.12.012.

Garrote, G., Rodríguez-Jasso, R.M., Ruiz, H.A., Romaní, A., Aguilar, C.N., Aguilar Reynosa, A., 2017. Comparison of microwave and conduction-convection heating 
autohydrolysis pretreatment for bioethanol production. Bioresour. Technol. 243, 273-283. https://doi.org/10.1016/j.biortech.2017.06.096.

Garrote, G., Ya, R., Alonso, L., Parajo, J.C., 2008. Coproduction of Oligosaccharides and Glucose from Corncobs by Hydrothermal Processing and Enzymatic Hydrolysis. Ind. Eng. Chem. Res. 1336-1345.

Ghose, T.K., 1987. Measurement of cellulase activities. Pure Appl. Chem. https://doi.org/ 10.1351/pac198759020257.

González-García, S., Morales, P.C., Gullón, B., 2018. Estimating the environmental impacts of a brewery waste-based biorefinery: Bio-ethanol and xylooligosaccharides joint production case study. Ind. Crops Prod. 123, 331-340. https://doi.org/10. 1016/j.indcrop.2018.07.003.

Hallborn, J., Walfridsson, M., Airaksinen, U., Ojamo, H., Hahn-Hagerdal, B., Penttila, M., Kerasnen, S., 1991. Xylitol production by recombinant Saccharomyces cerevisiae. Biotechnology. (N. Y). 9, 1090-1095.

Hamacher, T., Becker, J., Gardonyi, M., Hahn-Hagerdal, B., Boles, E., 2002. Characterization of the xylose-transporting properties of yeast hexose transporters and their influence on xylose utilization. Microbiology 148, 2783-2788. https://doi. org/10.1099/00221287-148-9-2783.

Hernandéz-Peréz, A.F., de Arruda, P.V., Sene, L., da Silva, S.S., Kumar Chandel, A., de Almeida Felipe, M., das, G., 2019. Xylitol bioproduction: state-of-the-art, industrial paradigm shift, and opportunities for integrated biorefineries. Crit. Rev. Biotechnol. 39, 924-943. https://doi.org/10.1080/07388551.2019.1640658.

Hu, J., Davies, J., Mok, Y.K., Gene, B., Lee, Q.F., Arato, C., Saddler, J.N., 2016. Enzymatic Hydrolysis of Industrial Derived Xylo-oligomers to Monomeric Sugars for Potential Chemical/Biofuel Production. ACS Sustain. Chem. Eng. 4, 7130-7136. https://doi. org/10.1021/acssuschemeng.6b02008.

Jesus, M.S., Romaní, A., Genisheva, Z., Teixeira, J.A., Domingues, L., 2017. Integral valorization of vine pruning residue by sequential autohydrolysis stages. J. Clean. Prod. 168, 74-86. https://doi.org/10.1016/j.jclepro.2017.08.230.

Jo, J.-H., Oh, S.-Y., Lee, H.-S., Park, Y.-C., Seo, J.-H., 2015. Dual utilization of NADPH and NADH cofactors enhances xylitol production in engineered Saccharomyces cerevisiae. Biotechnol. J. 10, 1935-1943. https://doi.org/10.1002/biot.201500068.

Jørgensen, H., Vibe-pedersen, J., Larsen, J., Felby, C., 2007. Liquefaction of Lignocellulose at High-Solids Concentrations. Biotechnology 96, 862-870. https:// doi.org/10.1002/bit.

Kogje, A., Ghosalkar, A., 2016. Xylitol production by Saccharomyces cerevisiae overexpressing different xylose reductases using non-detoxified hemicellulosic hydrolysate of corncob. 3 Biotech 6, 127. https://doi.org/10.1007/s13205-016-0444-4.

Kogje, A.B., Ghosalkar, A., 2017. Xylitol production by genetically modified industrial strain of Saccharomyces cerevisiae using glycerol as co-substrate. J. Ind. Microbiol. Biotechnol. 44, 961-971. https://doi.org/10.1007/s10295-017-1914-3.

Morales, A., Gullón, B., Dávila, I., Eibes, G., Labidi, J., Gullón, P., 2018. Optimization of alkaline pretreatment for the co-production of biopolymer lignin and bioethanol from chestnut shells following a biorefinery approach. Ind. Crops Prod. 124, 582-592. https://doi.org/10.1016/j.indcrop.2018.08.032.

Oliveira, C., Romaní, A., Gomes, D., Cunha, J.T., Gama, F.M., Domingues, L., 2018. Recombinant family 3 carbohydrate-binding module as a new additive for enhanced enzymatic saccharification of whole slurry from autohydrolyzed Eucalyptus globulus wood. Cellulose 25, 2505-2514. https://doi.org/10.1007/s10570-018-1722-6.

Olofsson, K., Bertilsson, M., Lidén, G., 2008. A short review on SSF - an interesting process option for ethanol production from lignocellulosic feedstocks. Biotechnol. Biofuels 1 , 7. https://doi.org/10.1186/1754-6834-1-7.

Palmqvist, E., Hahn-Hägerdal, B., 2000. Fermentation of lignocellulosic hydrolysates. I: inhibition and detoxification. Bioresour. Technol. 74, 17-24. https://doi.org/10. 1016/S0960-8524(99)00160-1.

Pereira, F.B., Guimaraes, P.M.R., Teixeira, J.A., Domingues, L., 2010. Selection of Saccharomyces cerevisiae strains for efficient very high gravity bio-ethanol fermentation processes. Biotechnol. Lett. 32, 1655-1661. https://doi.org/10.1007/s10529010-0330-9.

Pereira, F.B., Guimarães, P.M.R., Teixeira, J.A., Domingues, L., 2011. Robust industrial Saccharomyces cerevisiae strains for very high gravity bio-ethanol fermentations. J. Biosci. Bioeng. 112, 130-136. https://doi.org/10.1016/j.jbiosc.2011.03.022.

Pereira, Francisco B, Romani, A., Ruiz, H.A., Teixeira, J.A., Domingues, L., 2014a. Industrial robust yeast isolates with great potential for fermentation of lignocellulosic biomass. Bioresour. Technol. 161, 192-199. https://doi.org/10.1016/j.biortech.
2014.03.043.

Pereira, Francisco B., Romaní, A., Ruiz, H.A., Teixeira, J.A., Domingues, L., 2014b. Industrial robust yeast isolates with great potential for fermentation of lignocellulosic biomass. Bioresour. Technol. 161, 192-199. https://doi.org/10.1016/j.biortech. 2014.03.043.

Pinheiro, T., Coelho, E., Romaní, A., Domingues, L., 2019. Intensifying ethanol production from brewer's spent grain waste: Use of whole slurry at high solid loadings. N. Biotechnol. 53, 1-8. https://doi.org/10.1016/j.nbt.2019.06.005.

Pino, M.S., Rodríguez-Jasso, R.M., Michelin, M., Ruiz, H.A., 2019. Enhancement and modeling of enzymatic hydrolysis on cellulose from agave bagasse hydrothermally pretreated in a horizontal bioreactor. Carbohydr. Polym. 211, 349-359. https://doi. org/10.1016/j.carbpol.2019.01.111.

Rivas, B., Torre, P., Dominguez, J.M., Converti, A., Parajo, J.C., 2006. Purification of xylitol obtained by fermentation of corncob hydrolysates. J. Agric. Food Chem. 54, 4430-4435. https://doi.org/10.1021/jf053156x.

Rodríguez-López, J., Romaní, A., González-Muñoz, M.J., Garrote, G., Parajó, J.C., 2012. Extracting value-added products before pulping: Hemicellulosic ethanol from Eucalyptus globulus wood. Holzforschung 66, 591-599. https://doi.org/10.1515/hf2011-0204.

Romaní, A., Garrote, G., Alonso, J.L., Parajó, J.C., 2010. Bioethanol production from hydrothermally pretreated Eucalyptus globulus wood. Bioresour. Technol. 101, 8706-8712. https://doi.org/10.1016/j.biortech.2010.06.093.

Romani, A., Pereira, F., Johansson, B., Domingues, L., 2015. Metabolic engineering of Saccharomyces cerevisiae ethanol strains PE-2 and CAT-1 for efficient lignocellulosic fermentation. Bioresour. Technol. 179, 150-158. https://doi.org/10.1016/j.biortech. 2014.12.020.

Romaní, A., Ruiz, H.A., Pereira, F.B., Domingues, L., Teixeira, J.A., 2014a. Effect of hemicellulose liquid phase on the enzymatic hydrolysis of autohydrolyzed Eucalyptus globulus wood. Biomass Convers. Biorefinery 4, 77-86. https://doi.org/10.1007/ s13399-013-0093-3.

Romaní, A., Ruiz, H.A., Pereira, F.B., Teixeira, J.A., Domingues, L., 2014b. Integrated approach for effective bioethanol production using whole slurry from autohydrolyzed Eucalyptus globulus wood at high-solid loadings. Fuel 135, 482-491. https://doi.org/ 10.1016/j.fuel.2014.06.061.

Ruiz, H.A., Conrad, M., Sun, S.-N., Sanchez, A., Rocha, G.J.M., Romaní, A., Castro, E., Torres, A., Rodríguez-Jasso, R.M., Andrade, L.P., Smirnova, I., Sun, R.-C., Meyer, A.S., 2020. Engineering aspects of hydrothermal pretreatment: From batch to continuous operation, scale-up and pilot reactor under biorefinery concept. Bioresour. Technol. 299, 122685. https://doi.org/10.1016/j.biortech.2019.122685.

Salli, K., Lehtinen, M.J., Tiihonen, K., Ouwehand, A.C., 2019. Xylitol's Health Benefits beyond Dental Health: A Comprehensive Review. Nutrients 11, 1813. https://doi. org/10.3390/nu11081813.

Sheldon, R.A., 2018. The Road to Biorenewables: Carbohydrates to Commodity Chemicals. ACS Sustain. Chem. Eng. 6, 4464-4480. https://doi.org/10.1021/ acssuschemeng.8b00376.

Subtil, T., Boles, E., 2012. Competition between pentoses and glucose during uptake and catabolism in recombinant Saccharomyces cerevisiae. Biotechnol. Biofuels 5, 14. https://doi.org/10.1186/1754-6834-5-14.

Tada, K., Kanno, T., Horiuchi, J., 2012. Enhanced Production of Bioxylitol from Corn Cobs by Candida magnoliae. Ind. Eng. Chem. Res. 51, 10008-10014. https://doi.org/ 10.1021/ie202800h.

Tomás-Pejó, E., Bonander, N., Olsson, L., 2014. Industrial yeasts strains for biorefinery solutions: Constructing and selecting efficient barcoded xylose fermenting strains for ethanol. Biofuels, Bioprod. Biorefining 8, 626-634. https://doi.org/10.1002/bbb. 1472.

Weier, A.J., Glatz, B.A., Glatz, C.E., 1992. Recovery of propionic and acetic acids from fermentation broth by electrodialysis. Biotechnol. Prog. 8, 479-485. https://doi.org/ 10.1021/bp00018a002.

Xiros, C., Olsson, L., Koppram, R., Toma, E., 2014. Lignocellulosic ethanol production at high-gravity: challenges and perspectives 32 . https://doi.org/10.1016/j.tibtech. 2013.10.003.

Xu, Q.Q., Zhao, M.J., Yu, Z.Z., Yin, J.Z., Li, G.M., Zhen, M.Y., Zhang, Q.Z., 2017. Enhancing enzymatic hydrolysis of corn cob, corn stover and sorghum stalk by dilute aqueous ammonia combined with ultrasonic pretreatment. Ind. Crops Prod. 109, 220-226. https://doi.org/10.1016/j.indcrop.2017.08.038. 